\title{
Expression of somatostatin receptors may guide the use of somatostatin receptor imaging and therapy in differentiated thyroid cancer
}

\author{
Giorgio Treglia, ${ }^{1}$ Guido Rindi, ${ }^{2}$ Vittoria Rufini ${ }^{1}$ \\ ${ }^{1}$ Institute of Nuclear Medicine, ${ }^{2}$ Institute of Pathology, Catholic University of the Sacred Heart, Rome, Italy
}

Thyroid carcinoma is the most frequent type of endocrine tumour. Most differentiated thyroid cancers (DTCs) have an excellent prognosis if diagnosed early and treated appropriately. Nevertheless, a number of patients with DTCs do not achieve remission after thyroidectomy and subsequent radioiodine administration, showing local or metastatic disease unresponsive to radioiodine treatment because of lack of radioiodine uptake by the dedifferentiated tumour cells. ${ }^{1}$ Therefore, other therapeutic strategies could be helpful for metastatic DTCs refractory to radioiodine, for example, novel treatment options using radiolabeled somatostatin analogues. The rationale for somatostatin-based treatment should be the expression of somatostatin receptors in thyroid tumour cells, which allows diagnostic imaging and therapy by using radiolabeled somatostatin analogues. ${ }^{2,3}$ The majority of currently available somatostatin analogues

Key words: Differentiated thyroid cancer, Endocrine tumors, Imaging, Nuclear medicine, Somatostatin analogues, Somatostatin receptors, Therapy

\footnotetext{
Address for correspondence:

Giorgio Treglia, MD, Institute of Nuclear Medicine, Catholic University of the Sacred Heart, Largo Gemelli, 8; 00168 Rome, Italy, Tel.: +39 0630156200, Fax: +39 063013745; e-mail: giorgiomednuc@libero.it

Received 31-05-12, Revised 10-06-12, Accepted 30-06-12
}

for diagnosis and therapy show a high binding affinity for somatostatin receptor subtype $2 .^{2}$

Some studies assessed the expression of somatostatin receptors in thyroid tumours, in particular medullary thyroid carcinomas. ${ }^{4}$ Results of somatostatin receptor detection in other thyroid diseases like DTCs are still scarce and often controversial, depending on the investigational method used (Table 1)..$^{5-11}$

In their article published in Hormones, PazaitouPanayiotou et $\mathrm{al}^{5}$ have characterized the expression of somatostatin receptor subtypes in 47 cases of non-medullary thyroid carcinomas, thus providing a basis for future development of imaging and therapy with somatostatin analogues for patients with thyroid cancer who fail to respond to conventional therapies. Immunohistochemical staining was performed with five different polyclonal somatostatin receptor antibodies. These authors demonstrated that there was a high expression of all types of somatostatin receptors in human non-medullary thyroid carcinoma tissue, while the expression of somatostatin receptors was low or absent in the non-neoplastic thyroid tissue obtained from the same surgical material. Somatostatin receptor subtypes 2 and 3 appeared to be the most abundantly expressed..$^{5}$

Immunohistochemical staining can reveal the cellular and subcellular pattern of somatostatin receptor expression. This technique has also been used in another study to demonstrate the expression of somatostatin receptor subtype 2 in different thyroid 
Table 1. Expression of somatostatin receptors subtypes in non-medullary thyroid cancer: studies from the literature with more than 5 malignant thyroid tumours

\begin{tabular}{|c|c|c|c|}
\hline Authors & Thyroid tumours evaluated & Methods & Somatostatin receptors detected \\
\hline $\begin{array}{l}\text { Pazaitou- } \\
\text { Panayiotou } \\
\text { et al } 2012^{5}\end{array}$ & $\begin{array}{l}47 \\
(38 \text { PCs, } 4 \text { FCs, } 2 \text { ACs, } 3 \\
\text { HCCs) }\end{array}$ & $\begin{array}{l}\text { Immunohistochemisty for all } \\
\text { SSTRs subtypes }\end{array}$ & $\begin{array}{l}\text { SSTR } 2 \text { and } 3 \text { were expressed in all non-medullary } \\
\text { thyroid carcinomas, SSTR } 1 \text { and } 5 \text { in } 75 \% \text { and } \\
\text { SSTR } 4 \text { in } 38 \% \text {. The expression of SSTRs subtypes } \\
\text { in normal thyroid tissue was low or absent. }\end{array}$ \\
\hline $\begin{array}{l}\text { Müssig } \\
\text { et al } 2012^{7}\end{array}$ & $\begin{array}{l}93 \\
(67 \mathrm{PCs}, 26 \mathrm{FCs})\end{array}$ & $\begin{array}{l}\text { Immunohistochemisty for all } \\
\text { SSTRs subtypes }\end{array}$ & $\begin{array}{l}\text { SSTR } 1 \text { to } 5 \text { were detected in } 15 \% \text { to almost } 30 \% \\
\text { of thyroid tumours. }\end{array}$ \\
\hline $\begin{array}{l}\text { Sancak } \\
\text { et al } 2010^{6}\end{array}$ & $17 \mathrm{PCs}$ & $\begin{array}{l}\text { Immunohistochemisty for } \\
\text { SSTR } 2\end{array}$ & SSTR subtype 2 was expressed in PCs. \\
\hline $\begin{array}{l}\text { Klagge } \\
\text { et al } 2010^{8}\end{array}$ & $\begin{array}{l}45 \\
(20 \text { PCs, } 20 \text { FCs, } 5 \text { ACs })\end{array}$ & mRNA expression for SSTRs & $\begin{array}{l}\text { Thyroid tumours showed a predominant expression } \\
\text { of SSTR } 2 \text { and SSTR 5, and a weak expression of } \\
\text { SSTR } 1 \text { and SSTR } 3 \text {. }\end{array}$ \\
\hline $\begin{array}{l}\text { Druckenthaner } \\
\text { et al } 2007^{9}\end{array}$ & 17 & $\begin{array}{l}\text { mRNA expression for } \\
\text { SSTRs correlated with } \\
\text { immunochemistry for SSTR2 }\end{array}$ & $\begin{array}{l}\text { Thyroid tumours expressed SSTR 2, and less } \\
\text { predominantly SSTR } 3 \text { and } 5 .\end{array}$ \\
\hline $\begin{array}{l}\text { Forssell- } \\
\text { Aronsson } \\
\text { et al } 2000^{10}\end{array}$ & $9 \mathrm{PCs}$ and $2 \mathrm{HCCs}$ & mRNA expression & $\begin{array}{l}\text { All thyroid tumours regularly expressed SSTR 1, 3, } \\
\text { 4, and 5. SSTR } 2 \text { was not detected in PCs and was } \\
\text { irregularly expressed in HCCs. }\end{array}$ \\
\hline $\begin{array}{l}\text { Ain } \\
\text { et al } 1997^{11}\end{array}$ & $\begin{array}{l}\text { Cell lines derived from } 2 \\
\text { PCs, } 2 \text { FCs and } 4 \text { ACs }\end{array}$ & $\begin{array}{l}\text { mRNA expression for SSTRs } \\
\text { in thyroid cancer cell lines }\end{array}$ & $\begin{array}{l}\text { Most thyroid cancer cell lines expressed SSTR } 3 \\
\text { and } 5 .\end{array}$ \\
\hline
\end{tabular}

PCs: papillary carcinomas; FCs: follicular carcinomas; ACs: anaplastic carcinomas; HCCs: Hürthle cell carcinomas; SSTRs: somatostatin receptors.

diseases, including 17 papillary carcinomas. ${ }^{6}$ On the other hand, in a recent study of Müssig K et al, ${ }^{7} \mathrm{im}$ munohistochemical analysis revealed the expression of somatostatin receptors only in one third of patients with DTC in contrast with the results of PazaitouPanayiotou et al, ${ }^{5}$ underlining the fact that this topic is still controversial.

Several reports evaluated the expression of somatostatin receptors in non-medullary thyroid tumours by using mRNA analysis. Klagge et $\mathrm{al}^{8}$ investigated the mRNA expression of different somatostatin receptor subtypes in benign and malignant thyroid tumours and compared them to normal surrounding thyroid tissues. Somatostatin receptor subtype 2 was the predominant subtype expressed in thyroid tumours (with a high expression pattern particularly in papillary carcinomas), this being in agreement with the results of the study of Pazaitou-Panayiotou et al. ${ }^{5}$

The discrepant findings in the literature as to somatostatin receptor expression in DTCs may result from methodological differences, such as analysis techniques (immunohistochemistry versus mRNA analysis through Northern blotting or reverse transcriptase polymerase chain reaction) and tissues analyzed (human thyroid tumour samples versus thyroid cancer cell lines) (Table 1).

Somatostatin receptor expression in DTCs may allow detection of iodine-negative tumours or metastatic disease via use of scintigraphy with somatostatin analogues labeled with Indium- $111^{10,12-20}$ or Technetium- $99 \mathrm{~m},{ }^{21-23}$ or positron emission tomography with Gallium-68-somatostatin analogues. ${ }^{2,24}$ So far, several studies have used somatostatin-based imaging methods with conflicting results, probably depending on the imaging protocol employed, size and site of the tumour lesions and differences in somatostatin receptor subtypes expression.

In conclusion, expression of somatostatin receptors could offer novel treatment options using somatostatin analogues labeled with Indium-111, Yttrium-90 or Lutetium-177 in the case of metastatic DTCs with deficient iodine uptake or refractory to conventional treatment, as demonstrated by some preliminary experiences. ${ }^{15,25-27}$ 


\section{REFERENCES}

1. American Thyroid Association (ATA) Guidelines Taskforce on Thyroid Nodules and Differentiated Thyroid Cancer, Cooper DS, Doherty GM, Haugen BR, et al, 2009 Revised American Thyroid Association management guidelines for patients with thyroid nodules and differentiated thyroid cancer. Thyroid 19: 1167-1214.

2. Ambrosini V, Fani M, Fanti S, Forrer F, Maecke HR, 2011 Radiopeptide imaging and therapy in Europe. J Nucl Med 52: Suppl 2: 42-55.

3. Treglia G, Castaldi P, Rindi G, Giordano A, Rufini V, 2012 Diagnostic performance of Gallium-68 somatostatin receptor PET and $\mathrm{PET} / \mathrm{CT}$ in patients with thoracic and gastroenteropancreatic neuroendocrine tumours: a meta-analysis. Endocrine 42: 80-87.

4. Papotti M, Kumar U, Volante M, Pecchioni C, Patel YC, 2001 Immunohistochemical detection of somatostatin receptor types 1-5 in medullary carcinoma of the thyroid. Clin Endocrinol 54: 641-649.

5. Pazaitou-Panayiotou K, Tiensuu Janson E, Koletsa T, et al 2012 Somatostatin receptor expression in non medullary thyroid carcinomas. Hormones [E-pub ahead of print]

6. Sancak S, Hardt A, Singer J, et al, 2010 Somatostatin receptor 2 expression determined by immunohistochemistry in cold thyroid nodules exceeds that of hot thyroid nodules, papillary thyroid carcinoma, and Graves' disease. Thyroid 20: 505-511.

7. Müssig K, Wehrmann T, Dittmann H, et al, 2012 Expression of the proliferation marker $\mathrm{Ki}-67$ associates with tumour staging and clinical outcome in differentiated thyroid carcinomas. Clin Endocrinol. DOI: 10.1111/j.1365-2265.2012.04343.x.

8. Klagge A, Krause K, Schierle K, Steinert F, Dralle H, Fuhrer D, 2010 Somatostatin receptor subtype expression in human thyroid tumours. Horm Metab Res 42: 237-240.

9. Druckenthaner M, Schwarzer C, Ensinger C, et al, 2007 Evidence for Somatostatin receptor 2 in thyroid tissue. Regul Pept 138: 32-39.

10. Forssell-Aronsson EB, Nilsson $\mathrm{O}$, Bejegård SA, et al, $2000{ }^{111}$ In-DTPA-D-Phe1-octreotide binding and somatostatin receptor subtypes in thyroid tumors. J Nucl Med 41: 636-642.

11. Ain KB, Taylor KD, Tofiq S, Venkataraman G, 1997 Somatostatin receptor subtype expression in human thyroid and thyroid carcinoma cell lines. J Clin Endocrinol Metab 82: 1857-1862.

12. Giammarile F, Houzard C, Bournaud C, Hafdi Z, Sassolas G, Borson-Chazot F, 2004 Diagnostic management of suspected metastatic thyroid carcinoma: clinical value of octreotide scintigraphy in patients with negative highdose radioiodine scans. Eur J Endocrinol 150: 277-283.

13. Christian JA, Cook GJ, Harmer C, 2003 Indium-111-labelled octreotide scintigraphy in the diagnosis and management of non-iodine avid metastatic carcinoma of the thyroid. Br J Cancer 89: 258-261.

14. Stokkel MP, Reigman HI, Verkooijen RB, Smit JW,
2003 Indium-111-Octreotide scintigraphy in differentiated thyroid carcinoma metastases that do not respond to treatment with high-dose I-131. J Cancer Res Clin Oncol 129: 287-294.

15. Görges R, Kahaly G, Müller-Brand J, Mäcke H, Roser HW, Bockisch A, 2001 Radionuclide-labeled somatostatin analogues for diagnostic and therapeutic purposes in nonmedullary thyroid cancer. Thyroid 11: 647-659.

16. Haslinghuis LM, Krenning EP, De Herder WW, Reijs AE, Kwekkeboom DJ, 2001 Somatostatin receptor scintigraphy in the follow-up of patients with differentiated thyroid cancer. J Endocrinol Invest 24: 415-422.

17. Valli N, Catargi B, Ronci N, et al, 1999 Evaluation of indium-111 pentetreotide somatostatin receptor scintigraphy to detect recurrent thyroid carcinoma in patients with negative radioiodine scintigraphy. Thyroid 9: 583-589.

18. Tisell LE, Ahlman H, Wängberg B, et al, 1999 Expression of somatostatin receptors in oncocytic (Hürthle cell) neoplasia of the thyroid. Br J Cancer 79: 1579-1582.

19. Garin E, Devillers A, Le Cloirec J, et al, 1998 Use of indium-111 pentetreotide somatostatin receptor scintigraphy to detect recurrent thyroid carcinoma in patients without detectable iodine uptake. Eur J Nucl Med 25: 687-694.

20. Baudin E, Schlumberger M, Lumbroso J, Travagli JP, Caillou B, Parmentier C, 1996 Octreotide scintigraphy in patients with differentiated thyroid carcinoma: contribution for patients with negative radioiodine scan. J Clin Endocrinol Metab 81: 2541-2544.

21. Kohlfuerst S, Igerc I, Gallowitsch HJ, et al, 2006 Is there a role for sandostatin treatment in patients with progressive thyroid cancer and iodine-negative but somatostatin-receptor-positive metastases? Thyroid 16: 1113-1119.

22. Rodrigues M, Li S, Gabriel M, Heute D, Greifeneder M, Virgolini I, 2006 99mTc-depreotide scintigraphy versus 18F-FDG-PET in the diagnosis of radioiodine-negative thyroid cancer. J Clin Endocrinol Metab 91: 3997-4000.

23. Gabriel M, Froehlich F, Decristoforo C, et al, 2004 99mTc-EDDA/HYNIC-TOC and (18)F-FDG in thyroid cancer patients with negative (131)I whole-body scans. Eur J Nucl Med Mol Imaging 31: 330-341.

24. Traub-Weidinger T, Von Guggenberg E, Dobrozemsky G, et al, 2010 Preliminary experience with (68)Ga-DOTAlanreotide positron emission tomography. Q J Nucl Med Mol Imaging 54: 52-60.

25. Gabriel M, Andergassen U, Putzer D, et al, 2010 Individualized peptide-related-radionuclide-therapy concept using different radiolabelled somatostatin analogs in advanced cancer patients. Q J Nucl Med Mol Imaging 54: 92-99.

26. Teunissen JJ, Kwekkeboom DJ, Kooij PP, Bakker WH, Krenning EP, 2005 Peptide receptor radionuclide therapy for non-radioiodine-avid differentiated thyroid carcinoma. J Nucl Med 46: Suppl 1: 107-114.

27. Waldherr C, Schumacher T, Pless M, et al, 2001 Radiopeptide transmitted internal irradiation of non-iodophil thyroid cancer and conventionally untreatable medullary thyroid cancer using. Nucl Med Commun 22: 673-678. 